DOI: $10.21625 /$ archive.v2i2.242

\title{
The Impact of Tourism on the Cultural Environment in Turkey: The Case of Antalya
}

\author{
Şeyda ŞEN ${ }^{1}$ Yıldiz SALMAN $^{2}$ \\ ${ }^{1}$ İstanbul Kültür University \\ ${ }^{1}$ İstanbul Technical University
}

\section{Keywords \\ Tourism, Turkey, Cultural tourism}

\begin{abstract}
Tourism has begun to develop with the development of the socio-economic structures of the countries after the Second World War and has become one of the fastest growing and expanding sectors in the world economy since this period.

When tourism is rapidly growing, developing countries that have limited resources such as Turkey have to make rational investment decisions for the economic future of the country. Turkey's tourism policies that focus on coastal tourism began to be applied through development plans in the 1960s. In the five-year development plans that started in 1963, tourism was selected as the priority sector in the economic development of Turkey and the main principle of tourism sector was defined as mass tourism until the $1980 \mathrm{~s}$.
\end{abstract}

In this period when tourism investments were increasing, for the preservation of the natural and cultural heritage, it was aimed to give priority to the regions which were seen as most convenient for tourism investments.

In the 1960s, Antalya was one of the selected priority regions according to the directions of the development plans to concentrate on the regions with high ability to attract tourists and to get short-term results. After the 1980s, although the concept of individual tourism has been mentioned in the development plans, mass tourism investments in Antalya have increased rapidly with the Tourism Incentive Law No. 2634 issued in 1982. From the 1980s, accommodation facilities in various categories have filled the city, thus the negative impacts of tourism on the natural, cultural heritage and social structure have begun to become evident.

The tourism sector contributes greatly to the economic, cultural and social development of both developed and developing countries. However, the rapid and unplanned development of the tourism sector and focusing just on the economic impact of tourism for a long time has caused negative natural and socio-cultural influences.

In Antalya, overpopulation caused by the rapid development of tourism has caused deteriorations on the cultural and natural environment. Particularly, Kaleiçi which is the historic center of Antalya has been through cultural and social transformations and lost its original character.

The aim of this study which is based on the ongoing doctoral thesis is to discuss the role of tourism developments shaped by national policies and legal regulations with reference to the transformation process of cultural values in the case of Antalya Kaleiçi. In the first part of this study, national tourism policies and investments in Turkey and the interaction between them and the protection of the historic environment are explained. In the second part, the cultural, spatial and social impact of national tourism policies and investments in the case of Antalya are determined. 
In the third part, the spatial and social impacts of tourism investments in the case of Kaleiçi are questioned.

\section{National Tourism Policies and Investments in Turkey}

After the Second World War along with the improvement of the socio-economic structures of the countries, the demand for tourism increased rapidly and mass tourism became widespread. Due to widespread mass tourism and the economic achievements of the countries through tourism, tourism has begun to be seen as a tool for economic development. Since this period, tourism has become one of the fastest growing and expanding sectors in the world economy.

In this period when tourism was rapidly developing, developing countries such as Turkey which had limited resources had to make investment decisions rationally for the economic future of the country. The rapid development of the country's economy and the efficient use of limited resources had been attributed to determinate and plan of sectors that will provide the fastest and most revenue-generating growth (DPT, First Development Plan, 1963). For this purpose, since the early 1960s, the governments in Turkey has been prepared for development plans to determinate the priority sectors and its incentives.

In the five-year development plans that started in 1963, tourism was identified as the priority sector in the economic development of Turkey and the main principle of tourism policy was defined as mass tourism until the 1980s. Even though individual tourism investments were mentioned in the development plans since the 1980s, mass tourism investments were continued. Especially after the Tourism Incentive Law No. 2634, which was enacted in 1982 , mass tourism investments were increased in the Mediterranean and Aegean coastal regions, which were accepted as the most convenient regions for tourism.

In this period when tourism investments were increasing, for the preservation of the natural and cultural heritage, it was aimed to give priority to the regions which were seen most convenient for tourism investments. It was also clarified that conservation of national parks and restoration of historical monuments will take place in complementary investments (DPT, Second Development Plan, 1968).

Right after the acceptance of Tourism Incentive Law No. 2634 which includes the principles for the development of the tourism sector, the regulations to determine and plan tourism areas was accepted. Within this scope, from 1982 to nowadays, plans were made to target more than one million capacity of bed in tourist areas in the Mediterranean and Aegean coastal regions and nearly five hundred thousand capacity of the bed was accomplished (Doğmuş, 2010). Although this rapid and intense tourism development's negative impacts on the natural and cultural heritage values have been felt since the 1990s, the situation is defined as a problem in the development plans since the 2000s. In the Ninth Development Plan prepared in 2007, the negative impacts on the natural and cultural environment and urbanization pressure on tourism areas due to the tourism investments was defined as an important problem. (DPT, Ninth Development Plan, 2007).

As a result, national tourism policies, legal regulations and the tourism plans in Turkey have focused only on the economic benefits of tourism, especially the increase of the bed capacity in the coastal areas. In these coastal areas where natural and cultural heritage values are intense, instead of evaluating tourism and economic benefit of it as a tool for preserving these heritage values, these heritage values have been seen as a tool for the economic benefit that tourism can provide. To summarize, the preservation of these values has been highly connected to tourism and the motivation for preservation has been considered only because of the economic benefit it provides. The economic concerns over tourism planning stages have caused negative impacts on natural and cultural heritage. The tourism sector which is supported by multiple laws and incentives has transformed natural and cultural heritage into products that can be consumed for tourism purposes.

\section{The Impacts of National Tourism Policies and Investments in Antalya}

Until 1950s Antalya was a typical seaside city with a population of around 50.000 and had mainly agricultural and service sectors. The city consisted of the pier where today's yacht harbor is located, Kaleiçi and several quarters next to Kaleiçi (Esengil, 2002). The city has entered into a rapid transformation process with the tourism policies that started to apply since 1960 's.

Turkey's national tourism policies that focus on coastal tourism began to be applied through development plans in the 1960s. In this period, Antalya was one of the selected priority regions according to the first development plan decisions to concentrate on the regions with high ability to attract tourists and to get short-term results.

At the end of the 1960s, tourism planning studies were started in Antalya. In 1969 the coastal band between Antalya and Çanakkale was declared as Tourism Development Zone by Council of Ministers and it was decided to plan the 
coastal band with its $3 \mathrm{~km}$ inland from the coast. In this plan, Antalya came into prominence and became an important center within this band because of its well-conserved natural and cultural heritage values.

In the 1970s, in development plans, it was announced that construction of infrastructure, airport, marina, and highways will be carried out in the priority tourism areas (DPT, Third Development Plan1, 1973). To achieve this goal, in 1973, the Ministry of Tourism was invited Scandinavian Planning and Development Organization (SPDA) to prepare Antalya's master plans. In the same period, Antalya Region Tourism Master Plan was prepared. Thus this period has been the beginning of tourism-oriented urbanization in Antalya.

In 1975, three important projects were started in Antalya: The Southern Antalya Project, which foresees 70.000 accommodation capacity in the west of Antalya, The Historical City of Side Project, which foresees 12.000 accommodation capacity in the east of Antalya and The Historical Site Conservation Project of Kaleiçi.

After the 1980s, mass tourism investments in Antalya have increased rapidly with the Tourism Incentive Law No. 2634 issued in 1982 and the incentives provided by the state. 30 tourism areas of a total of 270 tourism areas which declared up to today from 1982, were located in Antalya. Antalya had the largest share of tourism investments in Turkey (Doğmuş, 2010). In this period, when certified accommodation capacity is about 10 times higher in Turkey, the accommodation capacity in Antalya had been \% of Turkey's total.

The number of tourist in Turkey in 1980 was 1.3 million and in 2015 the number of tourists was increased 27 times and became 36 million. Between 1980 and 2015, Antalya's percent from the total tourist number was increased parallel to the investments. In the same period, a number of tourist in Antalya in 1980 was 4.903 and in 2015 it became 11 million. Tourist percent of Antalya from the total number of tourists in Turkey was $\% 0,4$ in 1980, \%2,5 in 1985 and \%31 in 2015 (Esengil, 2002).

Table 1. Number of tourists coming to Turkey and Antalya by years

\begin{tabular}{|l|c|c|c|c|c|c|}
\hline & 1980 & 1985 & 1990 & 1995 & 2000 & 2015 \\
\hline Antalya & 4.903 & 65.915 & 826.027 & 1.939 .477 & 3.230 .837 & 11.331 .840 \\
\hline Turkey & 1.288 .060 & 2.614 .924 & 5.389 .308 & 7.726 .886 & 10.428 .153 & 36.244 .632 \\
\hline
\end{tabular}

Although Antalya has strong cultural tourism potential, which was the reason of the city was selected as a priority area in the 1960s, tourism investments have developed along the coastal tourism. From the 1980s, accommodation facilities in various categories have filled the city, thus the negative impacts of tourism on the natural, cultural heritage and social structure have begun to become evident. Accommodation facilities located side by side and even in some cases attached with the site areas in the region have threatened to preserve these areas.

In Antalya, tourism investments have created new types of services. Thus local people choose to work in the tourism sector, they abandoned their traditional crafts which is an important element of cultural tourism. The job opportunities have also caused immigration and overpopulation. And the social structure of city has been changed.

\section{The Impacts of National Tourism Policies and Investments in the Case of Kaleiçi}

Kaleiçi historical site is Antalya's historic city center which urban life constantly continuous since the 2nd century. Archaeological values from the Hellenistic and Roman ages that overlap with the historic city core; monumental values such as mosque, madrasa, hamam, church from the Seljuk and Ottoman periods; traditional urban values such as houses, shops, workshops, squares and gardens that show a section of the Ottoman urban life before the republic are the elements of the historical environment of the area. The traditional civil architecture of Kaleiçi which are dated the second half of the 19th century and the first half of 20th century is designed due to the local climate, topography, and landscape (Tankut, 1972).

Until 1950s Antalya was a typical seaside city with a population of around 50.000 and Kaleiçi was one of the several quarters in the city. In the 1950s due to immigration and urbanization, the population of Antalya has increased. Since the 1960's the city has entered into a rapid transformation process with the national tourism policies. Since the 1950s every development that occurred in Antalya has also affected the Kaleiçi site, because of its location in the city center.

At the end of the 1970s, the Ministry of Tourism decided the necessity of integrated tourism and conservation plan of Kaleiçi Historical Site because of the complex problems of it. Then the ministry gave the responsibility to prepare an integrated plan to Middle East Technical University’s Applied Research Unit (Tankut, 1972). 
Within the context of this plan, Kaleiçi was surveyed, analyzed and evaluated. Following the conservation and rehabilitation proposal plans developed for the study area in general scale, restoration and reuse projects were prepared.

As a result of the analyzes, it was stated that the economic structure of the area was weak and the environmental standards were low. In the survey studies that was done during this period, it was also determined that $\% 22$ of the commercial units were vacant and $\% 66$ of the houses and $\% 79$ of the commercial units were used by tenants (Tankut, 1972). Therefore, it is established that the increasing number of tenants and shortened duration of the tenancy, tend to turn the historical site into a transition zone. And the social erosion that can be a rise in the area, is highly relevant to the intense physical environment erosion.

Despite the threats on the area, Kaleiçi has the following the opportunities:

- The location close to the city center creates a great attraction.

- Natural and cultural heritage values of the site are very attractive.

- The environmental qualities such as the gardens can rarely find in the areas which are very close to the city center.

- The site has a very positive environmental balance for a city that has a tendency of rapid development and intense like Antalya.

- It has many vista points.

In Kaleiçi Historical Site Conservation Project, it was decided that tourism planning must not be a primary goal, but it can be a secondary goal of the project. The aim of the project was,

- to reduce the contradiction between the present situation of the historical environment and the contemporary life requirements.

- to repair the social structure

- to repair the economic structure

- to do a rehabilitation project

- to do a conservation project for the natural and cultural values

- to add touristic functions.

The main challenge of the project was whether or not the local people will continue to live in the same area again after the conservation project. The success of conservation plan was seen due to the facts that,

- to provide a healthy environmental structure for the local people.

- to create a healthy, functional and alive area for the city of Antalya (Tankut, 1972).

This plan, created by Middle East Technical University’s Applied Research Unit, was converted into a zoning plan and accepted in 1982. The zoning plan divided the area into five such as Kaleiçi historical site, archaeological sites, trade zone, accommodation zone, residential areas, green areas. In the plan, the ways of intervention in the registered buildings was determined. Accordingly, many buildings were restored and reused with functions related to the tourism sector (Yazar, 2010).

During the process of the plan, in the reuse projects, many registered buildings have lost their original plan scheme. Due to the increased value of the buildings and the new commercial functions brought to the area, the original users of the buildings have changed and the social structure has not been preserved.

In the 1980s, tourism investments that developed along the coastline of Antalya have also affected the Kaleiçi site. In 1992, the zoning plan was revised considering the tourism development that took place very close to the site. In the revised plan, it was declared as a necessity to function the new buildings as houses in order to sustain the integrity of the social structure. For preserve social structure, it was suggested to reuse some traditional houses as hostels and others as tourism function (Yazar, 2010).

Later on, the plan has been divided to prepare detailed projects by Antalya Metropolitan Municipality. In this context, restoration studies were carried out on the historic walls and registered houses of the site and landscape arrangements were made (Yazar, 2010).

In 2004, the Kaleiçi historical site was declared a "Cultural and Tourism Conservation and Development Zone" along with other historical sites in the city center. Later on, pedestrian and vehicle transports were arranged, infrastructure works and road covers were made, lighting elements were renovated and urban furniture was added. 
Recent studies in Kaleiçi historical site verified that tourism functions in the area have caused many problems that affect natural, cultural heritage and social structure. First of all, new buildings that are mostly incompatible with the environment has been increased. Increasing incompatible buildings can be a major problem that could cause to lose original characteristic of the area. Secondly, there has been a lack of maintenance for the monumental buildings. In the third place, as a result of the reuse projects that were focused on tourism functions, the original features (original plans and facades) of the registered buildings has been changed. In the fourth place, during the restorations, modern techniques and materials have been used instead of traditional materials and techniques. But the main problem in the site is, tourism-focused development of the city and the new tourism functions of the site, changes the social structure. While the local residents leave the site, the new people from other cities choose this site to live and work. Nowadays, more than $\% 50$ of the inhabitants are from the other cities.

\section{Conclusion}

The tourism sector contributes greatly to the economic, cultural and social development of both developed and developing countries. However, the rapid and unplanned development of the tourism sector and focusing just on the economic impact of tourism for a long time has caused negative natural and socio-cultural influences.

In the 1990s in addition to discussions on the negative effects of mass tourism on the cultural heritage, but also international tourist attractions have changed and tourists preferences have changed from coastal tourism to cultural tourism and alternative tourism types.

According to the United Nations World Tourism Organization, the main features of cultural tourism are; "Cultural tourism is also about experiencing and enjoying everything that makes the region, the life of local residents and the characteristics that make both of them." (UNWTO, 2004).

Integrated conservation, also pointed out by current conservation concepts, underscores that today's intangible cultural heritage such as daily life, traditional life, and modes of production must include as well as the physical structure to the protection planning studies of preservation areas. Particular attention should be paid to the fact that not to lose the spirit of the place, especially where tourism is economically beneficial.

Until 1950s Antalya was a typical seaside city with a population of around 50.000 and Kaleiçi was one of the several quarters in the city. In the 1950s due to immigration and urbanization, the population of Antalya has increased. Since the 1960's the city has entered into a rapid transformation process with the national tourism policies. Although Antalya has strong cultural tourism potential, which was the reason of the city was selected as a priority area in the 1960s, tourism investments have developed along the coastal tourism. From the 1980s, accommodation facilities in various categories have filled the city, thus the negative impacts of tourism on the natural, cultural heritage and social structure have begun to become evident.

Since the 1950s every development that occurred in Antalya has also affected the Kaleiçi site, because of its location in the city center. Although Kaleiçi Historical Site Conservation Project, which was created by Middle East Technical University's Applied Research Unit in the 1970s was aimed to local residents stay in the site, recent studies were showed that nearly $\% 50$ of the local residents left the site.

\section{References}

1. DPT, First Development Plan, 1963.

2. DPT, Second Development Plan, 1968.

3. DPT, Ninth Development Plan, 2007.

4. Doğmuş Eylem O., Antalya örneğinde ulusal turizm politikalarinin sorgulanmasi, Doctoral thesis, Dokuz Eylül University, Izmir, 2010.

5. Esengil, R., Antalya 20 yılda neden bu kadar bozuldu?, Journal of Mimarlık, Istanbul, 2002. issue:305, p. 60-62

6. Tankut, G., Antalya kaleiçi sit planlaması, Journal of Mimarlık, Istanbul, 1979. issue:159, p. 47-48.

7. Yazar, B., Turizmin tarihsel dokulara etkileri: Antalya örneği, Master thesis, Dokuz Eylül University, Izmir, 2010. 